\title{
Tainted Law? Why History Cannot provide the Justification for Abandoning Ius Sanguinis
}

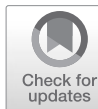

\author{
Jannis Panagiotidis
}

In his thought provoking piece, Costica Dumbrava rejects ius sanguinis as 1) historically tainted, 2) increasingly inadequate and 3) normatively unnecessary. In my response, I will mainly focus on the first, historical dimension. Drawing on examples from the case of Germany, often used as the prime example to show what is wrong with ius sanguinis, I will contest the idea that ius sanguinis as such has been discredited by history.

Regarding the second and third points, I will restrict myself to the following brief observations, which are broadly in line with Rainer Bauböck's comments: while the issue of ART and citizenship raised by Dumbrava is indeed intriguing, I would go along with his own observation that this is more about the determination of legal parentage than about ius sanguinis, and with Bauböck's emphasis on social rather than biological parenthood. Discarding the ius sanguinis principle due to certain specific cases it might not adequately cover would mean throwing the baby out with the bathwater.

I am also simultaneously intrigued and sceptical regarding the suggestion to introduce a sort of 'a-national', universal status for children. Against the backdrop of recent historical research into children as the object of nationalist contestation and agitation during the first half of the twentieth century, a scenario in which 'children belonged more rightfully to national communities than to their own parents', this idea appears intuitively attractive. ${ }^{1}$ Having said that, one can turn the argument around and see the suggested disconnection of parent and child citizenship as another attempt to claim children from their parents, this time on behalf on an imaginary inter- or supranational community. Yet in a world still (and for the foreseeable future) structured by nation states, where most so-called human rights are in fact citizens' rights,

1 Zahra, T. (2008), Kidnapped Souls: National Indifference and the Battle for Children in the Bohemian Lands, 1900-1948. Ithaca: Cornell UP, 3; See also: Zahra, T. (2011), The Lost Children: Reconstructing Europe's Families after World War II. Cambridge, MA: Harvard UP, 20. 
one may indeed wonder about the benefits of such a status 'above' or perhaps 'beyond' the nation if the parents cannot enjoy similar rights.

\section{Tainted by history?}

As to the argument of ius sanguinis being historically tainted, Dumbrava first of all needs to be commended for recognising that 'ius sanguinis citizenship is not conceptually "ethnic"". Nevertheless, he argues that "there are a number of ways in which the application of the ius sanguinis principle has been used in order to promote ethno-nationalist conceptions of membership'. These include 1) the maintaining of emigrant citizenship beyond the first generation of emigrants; 2) the use of 'the principle of descent in order to confirm or restore citizenship to certain categories of people whom [states] consider to be linked with through ethnocultural ties'; and 3) the exclusion of immigrant children from citizenship by an exclusive use of ius sanguinis with no ius soli elements.

Regarding the third point, I fully agree with Bauböck that it can be remedied quite easily by combining these two principles of citizenship allocation and simultaneously allow for residence-based naturalisation. The first issue is similarly unproblematic: extra-territorial transmission can simply be interrupted at a certain generational stopping point, much like the rule Germany introduced in section 4, paragraph 4 of its reformed 1999 citizenship law regarding the non-acquisition of German citizenship by the offspring of German citizens who themselves were born abroad after 31 December $1999 .{ }^{2}$ There is no rule that says that the transmission of citizenship to descendants has to be possible ad infinitum.

\section{Not all types of 'descent' are the same}

I would like to discuss the second point in more detail, which touches upon the topics of preferential membership policies and co-ethnic citizenship and migration. ${ }^{3}$ Here we are dealing with a terminological confusion quite typical for much of the literature in this field. The 'ethnic descent' that Dumbrava

2 Joppke, C. (2003), 'Citizenship Between De- and Re-Ethnicization', Russell Sage Foundation Working Paper No. 204, 12-13. The full text of the law can be found at: http://www.gesetze-im-internet.de/rustag/BJNR005830913.html

3 Dumbrava, C. (2014), Nationality, Citizenship and Ethno-National Belonging: Preferential Membership Policies in Europe. Basingstoke: Palgrave MacMillan; Panagiotidis, J. (2012), Laws of Return? Co-Ethnic Immigration to West Germany and Israel (1948-1992). PhD Diss., European University Institute. 
mentions as a criterion of admission to citizenship in some cases and the descent implied in the ius sanguinis principle are not the same and should not be conflated. In fact, they are mutually exclusive: 'descent' in ius sanguinis is about descent from a citizen, whatever his or her 'ethnicity'. The 'ethnic descent' used as a criterion in some cases of co-ethnic inclusion is precisely about people who are not citizens.

The supposed historical taintedness of the ius sanguinis principle results from the conflation of these different types of 'descent', and of the related unhappy connotations of the term 'blood', which invokes associations of 'race'. A lot of this confusion was created in the Brubaker-inspired debates of the 1990s about German citizenship. In a telling example, political scientist Patricia Hogwood claimed that 'the concept and law of citizenship in Germany were originally formulated in the context of nation-state development based on cultural or 'völkisch' nationalism. ... The fact that the German legal framework for citizenship and naturalisation remains firmly rooted in the jus sanguinis principle has meant that citizenship policy in Germany is inextricably entangled in concepts of ethnicity and race.... The principle of legal privilege [for ethnic Germans] on the basis of racial origins smacks of the racial policies of the Nazi period ...' (my emphasis, J.P.). ${ }^{4}$

Yet ius sanguinis per se has nothing to do with 'ethnicity' and 'race'. As Dieter Gosewinkel pointed out in his important book on German citizenship, the 'blood' here is a 'formal and instrumental' notion, not to be confused with 'substantial' blood conceptions of racial biology. ${ }^{5}$ Those only entered German citizenship law through the Nazi Nuremberg laws. Before, a German Jew, whom the Nazis would later construe to be of a different 'race' for having the wrong 'blood', would transmit his German citizenship to his children iure sanguinis, just like other Germans whom the Nazis would construe as 'Aryans'. Ius sanguinis is ethnicity-blind. In fact, when young Israelis nowadays claim German citizenship with reference to an ancestor who fled from Germany, they also do so iure sanguinis. I would find it hard to interpret this as an objectionable völkisch practice. This example shows that the problem is not with ius sanguinis itself, but with the respective contexts in which it is embedded.

4 Hogwood, P. (2000), 'Citizenship Controversies in Germany: the twin legacy of Völkisch nationalism and the Alleinvertretungsanspruch', German Politics 9 (3): 125-144, here 127, 132-133.

5 Gosewinkel, D. (2001), Einbürgern und Ausschließen: Die Nationalisierung der Staatsangehörigkeit vom Deutschen Bund bis zur Bundesrepublik Deutschland [Naturalising and Excluding: Nationalisation of Citizenship from the German Confederation to the Federal Republic of Germany]. Göttingen: Vandenhoeck \& Rupprecht, 327. 


\section{Co-ethnic citizenship is a different story}

Nor is ius sanguinis particularly useful (or even necessary) for the conveying of citizenship upon 'co-ethnics' in other countries. This is a whole different discussion in my opinion which cannot be used to make a case against the ius sanguinis principle. Taking again the example of Germany, the main European supplier of co-ethnic citizenship in past decades, it needs to be stressed that 'ethnic Germans' from Eastern Europe did not receive German citizenship by means of the ius sanguinis of the 1913 citizenship law. This was not possible, as in most cases they had no ancestor with German citizenship to refer to. Their claim to citizenship rested on special provisions in the constitution and expellee law, which equalised the status of German Volkszugehörige with that of German citizens.

At this point we leave the solid ground of formal citizenship and enter into the murky territory of 'ethnicity'. But even here, it is not all about 'descent'. While the peculiar notion of Volkszugehörigkeit is often identified with 'ethnic descent', it was much more complex than that: it was actually very much a political-plebiscitary notion predicated on self-avowal (Bekenntnis) as German to be confirmed by an 'objective' criterion, which could be language, descent, upbringing, or culture (section 6 of the 1953 Federal Expellee Law). 'Descent' (Abstammung) - notoriously hard to define in administrative practice - was thus neither a necessary nor a sufficient condition for recognition as a German. ${ }^{7}$

\section{Conclusion}

In sum, I would argue that the supposed 'taintedness' of ius sanguinis has to do with issues not intrinsic to this principle of transmitting citizenship, namely restrictive admission practices and racially based exclusion. The issue of co-ethnic citizenship should be kept apart from this discussion altogether. History cannot provide the justification for abandoning ius sanguinis, as its use in certain problematic ways and contexts in the past does

6 See: http://www.bgbl.de/xaver/bgbl/start.xav?startbk=Bundesanzeiger BGBl\&jumpTo=bgbl153022.pdf

7 I elaborate on the plebiscitary, quasi-'Renanian' nature of the German conception of Volkszugehörigkeit in: Panagiotidis, J. (2012), 'The Oberkreisdirektor Decides Who Is a German': Jewish Immigration, German Bureaucracy, and the Negotiation of National Belonging, 1953-1990. Geschichte und Gesellschaft 38, 503-533, esp. 511. 
not mean it necessarily has to be used like that in the future. If complemented by other, inclusionary mechanisms of allocating citizenship in conjunction with increased tolerance for multiple citizenship it certainly remains a useful - and necessary - method of transmitting citizenship in the day and age of multiple transnational migrations.

Open Access This chapter is licensed under the terms of the Creative Commons Attribution 4.0 International License (http://creativecommons.org/licenses/by/4.0/), which permits use, sharing, adaptation, distribution and reproduction in any medium or format, as long as you give appropriate credit to the original author(s) and the source, provide a link to the Creative Commons license and indicate if changes were made.

The images or other third party material in this chapter are included in the chapter's Creative Commons license, unless indicated otherwise in a credit line to the material. If material is not included in the chapter's Creative Commons license and your intended use is not permitted by statutory regulation or exceeds the permitted use, you will need to obtain permission directly from the copyright holder. 